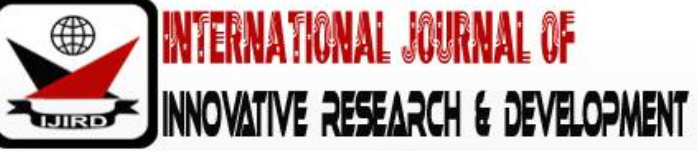

ISSN 2278 - 0211 (Online)

\section{Time Management: Critical Traps and Escape Strategies for School Administrators in Colleges of Education in North Western Nigeria}

\author{
Dr. Sani Dantani Manga \\ Associate Professor, Department of Educational Foundations, \\ Usmanu Danfodiyo University, Sokoto, Nigeria
}

\begin{abstract}
:
This paper examined time traps that affect School administrators in Colleges of Education in North-Western Nigeria as well as escape strategies, which they use in their attempt at time management. This study adopted a simple descriptive survey. The population of the study was made up of School administrators in 13 Colleges of Education out of which 10 were deliberately sampled from the seven states in North Western Nigeria which include Jigawa, Kaduna, Kano, Katsina Kebbi, Sokoto and Zamfara State. The Colleges comprised of five Federal and five State Colleges of Education. In each College, 200 School administrators were purposefully selected out of 380. A self-designed structured and validated questionnaire titled: "Time Traps and Escape strategies Questionnaire" (TTESQ) was used to collect dated. The instrument was pilot-tested and Pearson Product Moment Correlation Coefficient at 0.05 level of significance and it had a reliability index of 0.76.It was based on a five-point Likert scale. The data was analyzed using summative rating scale otherwise called weighted mean whereby the mean score of 2.50 and above was used as cut off for agreement while below 2.50 was used to decide disagreement. The findings of the study indicated that School administrators in Colleges of Education in North-Western Nigeria were affected by various kinds of time traps which include management by crisis, communication overload, drop in visitors, lack of delegation, multi-tasking and lack of use of time management tools among others. They tend to hold negative assumptions that affect their efforts at time management. Many of them were found not to use time management tools for escape strategies. It was recommended that executive workshops on time management be organized for School administrators using multi-disciplinary and multimedia approaches to help them to improve on their time management skills.
\end{abstract}

Keywords: Time, school administrators, time management

\section{Introduction}

Time management is a skill that seems to elude many school administrators. As an administrator, one is responsible for his own time and how those he supervises spend theirs. As a School Administrator one is faced with heavier workload and complex responsibilitieswith deadlines growing shorter. Insuch a situation it may seem that working overtime is the only way to get everything done. But it does not necessarily have to be that way if the school administrator manages his time properly. To Hornby (2015), time is defined as the duration it takes to accomplish a task usually measured in minutes, hours, days, weeks, months and years. Atibah (2001) views time as the period when an event has happened or is happening or shall happen, implying that it defines the past, present and the future. Arvidson (2017) sees time as the moment when opportunity to do something is at its highest.

From whatever perspective time is defined, it is clear that time is a very limited and scarce resource. That is why it is often said that time is money and as a precious commodity, it must be prudently managed by the School administrators. Time management in this regard, is the process of planning and exercising conscious control over the amount of time spent on specific activities especially with a view to increase efficiency and effectiveness (White: 2016). The School administrators must manage time properly if he is to attain higher level of productivity with minimum stress. The School administrators in this paper is operationalized and expanded to include Heads of Departments, Deans of Schools, Directors, Deputy Provosts and Provosts. They are the bosses in their various units of the Colleges they are heading. In order to manage time properly, the School administrators should be able to identify critical time traps and devise reliable escape strategies for prompt accomplishment of their tasks and statutory duties.

\section{Statement of the Problem}

It is generally accepted that no nation shall rise above the quality of its teachers (Fafunwa, 2014). Colleges of Education are specifically established to produce professionally qualified, competent, creative and highly motivated teachers to provide good quality of education (Federal Republic of Nigeria, 2013) But the quality of education in Nigeria 
seen to be far from the ideal as there is the general outcry on falling standards and low productivity among teachers. Part of the problem is from the half-baked training given to teachers resulting from non-coverage of syllabus in their course work, inadequate teaching practice supervision as well as poor project supervision. All of these challenges are partly blamed on lack of adequate time to accomplish the desired tasks. It is very common to hear of lecturers complaining of insufficient time to fully cover the syllabus, thoroughly mark numerous examination scripts and correct student projects. It is even worse with School administrators in Colleges of Education who are under excessive time constraint to chair numerous meetings, attend to numerous visitors, read and write several memos among others. Since the School administrators have to meet up with various deadlines there is a tendency to fall into different kinds of time traps. Mackenize and Nickerson (2009) identified critical time traps that may hook a School administrator to include management by crisis, inadequate planning of activities and lack of goal setting resulting in aimless drifting without focus, inability to say no to endless demands of people for attention, and communication overload. Tracy (2009) listed poorly run or ill prepared meetings, e-mail mania, untamed telephone interruptions, and poor delegation as time traps that affect many executives. Manser' (2010) in his view pointed out that procrastination, frequent drop-in-visitors, attempting too much, and complex multi-tasking as serious time traps common in organizations. Blanchard and Johnson (2003) pointed at lack of breaks, inadequate sleep, fatigue and lack of deadliness for accomplishing tasks as major time traps that affect task completion and goal attainment.

Apart from, obvious time traps, there are some erroneous and outdated assumptions that are held by workers generally and by some school administrators that tend to make them to neglect taking appropriate action to avoid falling into time traps. According to Nickels, McHough and Miltugh (2005), some school administrators do not feel the need to learn time management skills. They tend to assume that time management is a common sense affair and that they work best under pressure. Romara (2017) pointed out that some School administrators assume that they are too busy to learn about time management and that it may lead to loss of spontaneity in taking prompt actions and for efficient task performance.

In addition to erroneous assumptions which make school administrator prone to be victim of time traps, some school administrators do not appear to see the significance of using time management tools to help them escape and to avoid falling into time traps. Atilab (2001) notes that many school administrators do not keep a diary or notebook of their activities. They do not keep a check list and time table of crucial tasks that need routine attention. In addition, Bisk (2017) observes that some school administrators do not have things "to-do-list", they do not set alarms and reminders and do not feel the need to set deadlines as effective tools to assist them in timely accomplishment of tasks. The main thrust of this paper therefore is to identify critical time traps, the prevailing assumptions that lead to those traps and the time management tools that could serve as escape strategies for effective job performance among school administrators in Colleges of Education in North Western Nigeria.

\section{Objectives of the Study}

The objective of this study includes the following:

- To find out the time traps that affect School administrators in Colleges of Education in North Western Nigeria.

- To ascertain the assumptions that affect tithe management among School administrators in Colleges of Education in North-Western Nigeria

- To Examine time management tools that can be used to escape time traps by School administrators in Colleges of Educate in North-Western Nigeria

\section{Research Questions}

The following research questions were formulated to guide the study:

- What are time traps that affect school administrators in Colleges of Education in North Western Nigeria?

- What are the assumptions that affect time management among school administrators in Colleges of Education in North-Western Nigeria?

- What are the time management tools that are used to escape timetraps among School administrators in Colleges of Education in North Western Nigeria?

\section{Methodology}

This study adopted on simple descriptive survey. The population of the study was made u School administrators drawn from the Colleges of Education in North Western Nigeria. There are 13 Colleges of Education out of which 10 were deliberately sampled from the seven states in North Western Nigeria which include Jigawa, Kaduna, Kano, Katsina Kebbi, Sokoto and Zamfara State. The Colleges comprised offive Federal and five State Colleges of Education. A total sample of 200 participants were purposely sampled from the 10 schools. School administrators were operationalized to include the Provost, two Deputy Provost Librarian, and Registrar, Deans of Schools, Heads of Department and Directors. A selfdesigned, structured and validated questionnaire titled: "Time Traps and Escape strategies Questionnaire" (TTESQ) vas used to collect data: The instrument after being pilot tested and the result were analyzed using Pearson Product Moment Correlation Coefficient had a reliability index of 0.76 at 0.05 level of significance on a five-point scale. It was administered with the help of trained research assistants. The data was analyzed collectively based on a five-point Likert scale and using summative rating scale otherwise called weighted mean, whereby the mean score of 2.50 and above was used as cut off for agreement while below 2.5 was used to decide disagreement; 


\section{Results}

The data collected was analyzed and presented in line with the sequence of research questions reflected in tables

$1-3$.

6.1. Research Question One

- RQ1: What are the time traps that affect School administrators in Colleges of Education in North Western Nigeria?

This research question was answered and presented in table 1:

\begin{tabular}{|c|c|c|c|}
\hline S/ N & Types of Time Traps Affecting Executives & Mean & Decision \\
\hline 1 & Management by crisis & 2.63 & Agree \\
\hline 2 & Inadequate planning and goal setting & 3.00 & Agree \\
\hline 3 & Inability to say no to every demand & 2.74 & Agree \\
\hline 4 & Communication overload & 2.66 & Agree \\
\hline 5 & Poor communication & 2.01 & Disagree \\
\hline 6 & Ill-prepared meetings & 3.50 & Agree \\
\hline 7 & Poorly run meeting & 3.50 & Agree \\
\hline 8 & Email mania & 3.50 & Agree \\
\hline 9 & Unnamed telephone interactions & 3.20 & Disagree \\
\hline 10 & Drop in visitors and employee's interruption & 4.00 & Agree \\
\hline 11 & Lack of delegation of work & 2.40 & Disagree \\
\hline 12 & Attempting too much & 3.70 & Agree \\
\hline 13 & Multi-tasking & 3.00 & Agree \\
\hline 14 & Lack of breaks & 3.00 & Agree \\
\hline 15 & Lack of deadlines & 2.08 & Disagree \\
\hline 16 & Unrealistic deadlines & 3.03 & Agree \\
\hline 17 & Being too hard on oneself & 3.61 & Agree \\
\hline 18 & Lack of adequate exercise & 3.03 & Agree \\
\hline 19 & Lack of adequate sleep & 3.09 & Agree \\
\hline 20 & Improper diet & 3.70 & Agree \\
\hline & Overall Mean & 3.37 & Agree \\
\hline
\end{tabular}

Table 1: Mean Scores on Types of Time Traps Which Affect School Administrators in

Colleges of Education in North Western Nigeria

Table 1 shows that majority of the participants do not agree with items 5,7,11 and 15 which had mean scores of $2.01,2.30,2.40$ and 2.08 respectively. That is to say they do not agree that poor communication, poorly run meeting, lack of delegation and lack of deadlines are critical time traps that affect them. This means that they save time by good communication, efficiently run meeting, proper delegation and working within the deadlines or timeframes. However, they agreed that they fall into time traps of managing by crisis, inadequate planning, inability to say no to endless demands, communication overload, ill prepared meetings, e-mail mania, telephone interruptions, drop-in-visitors, attempting too much, multi-tasking, lack of breaks, unrealistic deadlines, being too hard on themselves, inadequate sleep, exercise and diet, which were rated between mean scores of 2.3 and 4.40. The overall mean of 3.37 shows that as a whole school administrator in Colleges of Education in North Western Nigeria were affected by all the time traps.

\subsection{Research Question Two}

- RQ2: What are the assumptions that time management among school administrators in Colleges of Education in North Western Nigeria?

This research question was answered and presented in table 2:

\begin{tabular}{|c|c|c|c|}
\hline S/ N & Assumptions Management & Mean & Decision \\
\hline 1 & Time management is a common sense affair & 3.10 & Agree \\
\hline 2 & One works best under pressure & 3.50 & Agree \\
\hline 3 & One is too busy to learn about time management & 3.00 & Agree \\
\hline 4 & Time management may lead to loss of spontaneity & 3.30 & Agree \\
\hline 5 & One-time management tool is enough & 3.40 & Agree \\
\hline & Overall Mean & 3.25 & Agree \\
\hline
\end{tabular}

Table 2: Mean Scores of Assumptions That Affect Time Management among School Administrators In Colleges of Education in North Western Nigeria

Table 2 indicated that the participants agreed that all the assumptions listed in table 2 affect time management efforts by school administrators as the items had mean scores of between 3.00 to 3.50 which places them above the cut of 
mean 2.50 for agreement. The overall mean of 3.25 shows that the participants agreed that school administrator in Colleges of Education in North Western Nigeria hold negative assumptions that affect their efforts at time management.

\subsection{Research Question Three}

- RQ2: What are the time management tools that are used to escape time traps among school administrators in Colleges of Education in North Western Nigeria?

This research question was answered and presented in table 3:

\begin{tabular}{|c|c|c|c|}
\hline S/ N & Assumptions Management & Mean & Decision \\
\hline 1 & Keeping a diary or notebook & 2.00 & Disagree \\
\hline 2 & Keeping a checklist of activities & 2.06 & Disagree \\
\hline 3 & Use of time table for operative tasks & 2.40 & Disagree \\
\hline 4 & Keeping a to-do-list & 2.13 & Disagree \\
\hline 5 & Setting alarms and reminders & 2.18 & Disagree \\
\hline 6 & Setting deadlines & 3.92 & Disagree \\
\hline & Overall Mean & 2.13 & Disagree \\
\hline
\end{tabular}

Table 3: Mean of Time Management Tools to Be Used To Escape Time Traps among School Administrators in Colleges of Education in North Western Nigeria

Table 3 shows that apart from setting deadlines a mean score of 3.92, the participants disagreed on the use of diaries, notebooks, checklist, keeping "to-do-list", setting alarm and reminders as time management tools as the items had mean scores ranging from 2.00 to 2.40 which all fall below the cut of mean of 2.5. The overall mean of 2.13 shows that school administrators in Colleges of Education in North Western Nigeria do not use effective time management tools to escape time traps that confront them on daily basis.

\section{Summary of Findings}

Based on the analysis of data presented tables 1,2,3 the following findings were made;

- School administrators in Colleges of Education in North Western Nigeria were affected by various kinds of time traps in the course of their work. These include; management by crisis, e-mail mania, multitasking, communication overload, telephone mania among others.

- School administrators in Colleges of Education in North Western Nigeria held erroneous assumptions that negatively affect their effort at time management. These includes; the assumptions that time management is a common sense affair, one works better under pressure and being too busy to study time management among others.

- School administrators in Colleges of Education in North Western Nigeria do not use effective time management tools to escape time traps that confront them on daily basis. These neglected time management tools include; keeping of diaries, notebooks, checklist, to-do-list, setting deadlines and alarms for reminders among others.

\section{Discussion of Findings}

The findings of this study show that school administrators in Colleges of Education in North Western Nigeria were affected by various time traps. These findings agreed with Mackenzie and Nickerson (2009), Tracy(2009) and Minser (2010) who in their various submissions identified critical time traps affecting school administrators to include management by crisis, inability to say no to endless demands, communication overload, ill prepared meetings, email mania and frequent interruption by drop-in-visitors, subordinates, inadequate delegation, unrealistic deadline among others. But in spite of the good knowledge of the school administrators on various time traps, virtually very little or no effort is done by them to avoid the time traps.

The second finding of this study was school administrators in Colleges of Education in North Western Nigeria hold negative assumptions that discourage them from taking decisive actions to avoid time trap. These findings tallies with Nickels, McHugh and McHugh (2005)and Romara (2017) who highlighted a number of old time assumptions that school administrators hold about time traps to include the assumptions that time management is a common sense affair, that they work based under pressure, they are too busy to learn about time management and that it may lead to loss of spontaneity in action. These assumptions are retrogressive, conservative and erroneous. They tend to persist probably because school administrators in Colleges of Education in North Western Nigeria have not taken time to study abundant literature on time traps and time management technique. Even in some cases where they do, they find it difficult to drop their old time deeply embedded opinions about time management as their wrong assumptions are widely spread.

The third finding of this study showed that school administrators in Colleges of Education in North Western Nigeria do not use effective time management tools to escape time traps that confront them on daily basis. The finding agrees with Atilab (2001) and Bisk (2017) who noted that many school administrators do not see the need to use time management tools and went further to identify time tested management tools to include; keeping a diary or notebook, checklist, time table, a to do list, alarms and reminders as well as setting realistic deadlines. The neglect of this time management tools may be as a result of lack of information and proper investigation by school administrators on time management tools they can use to help them escape time traps. 


\section{Conclusions}

Although School administrators in Colleges of Education in North Western Nigeria were affected by various time traps yet they tend to hold erroneous assumptions that affect their efforts at time management efforts. This tend to account for why they do not keenly use effective time management strategies to help them escape from various time traps existing in various manifestations.

\section{Recommendations}

Based on the findings of the study, the following recommendations were made:

- Management experts should emphasize workshops on time management targeted at exposing the dangers of time traps on School administrators in Colleges of Education in North Western Nigeria. This many ginger them to recognize the negative effect of time traps on their productivity.

- Educational management experts should liaise with experts in other relevant fields such as economist and psychologists in order to help School administrators in North Western Nigeria to modify and drop erroneous assumptions about time management. This will enable them to have a rational understanding of time as a limited resource.

- Educational management experts should use multimedia approaches to popularize the existence of time management tools that can be used by School administrators in Colleges of Education for more efficient and effective administration of the Colleges.

\section{References}

i. Arrvidson, N. (2017). Seven ways to improve time management Online: http:/ Avww.recrutier.corn.inc Retrieved 30/10/17.

ii. Atibah, J (1991) How to manage your tune Training guide for Islamic workers InternationalIslamic Federation of Students Organization and International Institute for Islamic Thought Human Development Series No I Heredon, Virginia, U.S.A.

iii. Bisk, A.D. (2017). Essentials of business management. Online: https:/ Avww.essentialsofbusrnessufexec.ufl.eclu7

iv. Blancharci, K. \&Johnson, S. (2003). The one-minute manager. New York. Hàtper Collins publishers Inc

v. Fafunwu, A.B. (2014). History of Education in Nigeria. London. Oxford Universities Press. Qes So, J. (2017). New Approaches to time management. Online: htn: Hwww.aoi.con,. >articies Retrieved $30 / 10 / 2017$.

vi. Harmby A.S. (2003). Oxford Advanced Learner's Dictionary. International student's edition. New York. Oxford University press.

vii. Mackenzie, A \& Nickerson,'P. (2009). The time trap: A classic book on time management. Benin Citty. Marrchous Christian Publications.

viii. Manser, M. (2010). Time management secrets: Business secrets the secrets the experts tell all. London: Harper Collins Publishers.

ix. $\quad$ Nickles, MG., McHugh, J.M \& McHugh S.M. (2005), Understanding business. New York. McGraw-Hill 7th ed.

x. Romara, C. (2017). Time management in corporate organization. Online: HTTPs.;L/ jyww.srnead.com7tirnemanagement Retrieved 30/ 10/ 2017.

xi. Tracy, B. (2007). Eat that frog. 21 ways to stop procrastinating and get more done in less time. Benin City: Joint Heirs publications Nigeria Ltd.

xii. White, D. (2016). Six tips to improve your time management skills. Online: hjpsLpsychoccntral com/lib/ 6 tips to improve year-time-management-shill retriev 